\title{
A pediatric case of pigeon breeder's disease in Nova Scotia
}

\author{
Ellen Tsai MD ${ }^{1}$, Dominique Couture $\mathrm{MD}^{2}$, Daniel M Hughes MD ${ }^{1}$ \\ ${ }^{1}$ Department of Pediatrics, Dalhousie University, Halifax, Nova Scotia; \\ ${ }^{2}$ Yarmouth Regional Hospital, Yarmouth, Nova Scotia
}

\section{E Tsai, D Couture, DM Hughes. A pediatric case of pi- geon breeder's disease in Nova Scotia. Can Respir J 1998:5(6):507-510.}

Pigeon breeder's disease has been reported sporadically in the pediatric population since it was first described in children in 1967. Because of its infrequent occurrence in children, a high level of suspicion is often required before a diagnosis is made. A case of pigeon breeder's disease in a child in Nova Scotia, where the disease is virtually unseen or at least unrecognized, is described. The need for prompt recognition of the condition is paramount because its complications may be irreversible.

Key Words: Hypersensitivity pneumonitis, Interstitial lung disease, Pigeon breeder's disease

\section{Cas pédiatrique de maladie des éleveurs de pi- geons en Nouvelle-Écosse}

RÉSUMÉ : La maladie des éleveurs de pigeons est signalée de façon sporadique dans la population pédiatrique depuis qu'elle a été décrite pour la première fois chez l'enfant en 1967. À cause de sa faible incidence chez l'enfant, un niveau de présomption élevé est souvent nécessaire avant qu'on la diagnostique. On décrit un cas de maladie des éleveurs des pigeons chez un enfant habitant en Nouvelle-Écosse, où cette maladie ne se rencontre pratiquement pas ou du moins est méconnue. Il faut absolument reconnaître rapidement cette maladie parce que les complications qu'elle entraîne peuvent être irréversibles.
$\mathrm{P}$ igeon breeder's disease has been reported sporadically in the pediatric population since it was first described in children in 1967 by Stiehm et al (1). Because of its infrequent occurrence in children, a high level of suspicion is often required before a diagnosis is made. We describe a case of pigeon breeder's disease in a child in Nova Scotia, where the disease is virtually unseen or at least unrecognized. The need for prompt recognition of the condition is paramount because while treatment can be simple, complications may be irreversible.

\section{CASE PRESENTATION}

A seven-year-old girl presented to her family doctor with a two-month history of gradual onset dyspnea, accompanied by anorexia, decreased energy and intermittent low grade fever. Her parents had noted that she had increasing difficulty walking up the small hill from the school bus stop to their home, although she was not dyspneic at rest. She also had a nonproductive cough, with coughing spasms associated with cyanosis. At this time, she was started on antibiotics. Two weeks later when she had failed to improve a chest x-ray was 


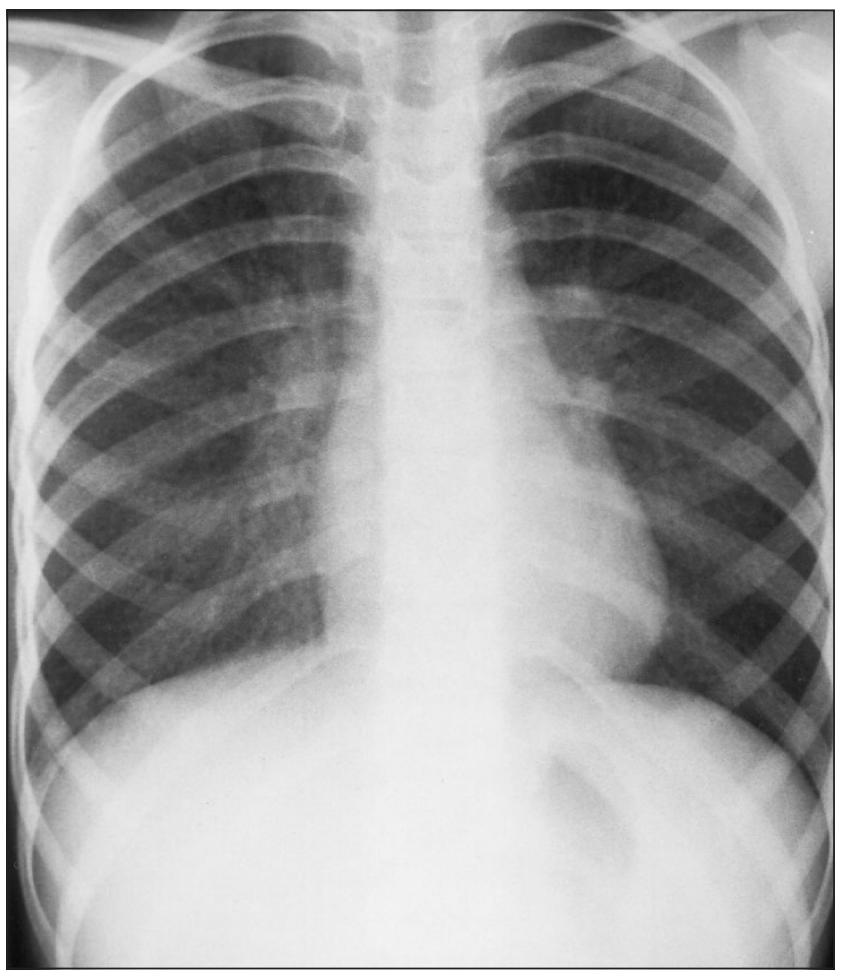

Figure 1) Chest $x$-ray demonstrating nodular interstitial changes on initial presentation

performed, and she was prescribed erythromycin for what was thought to be pneumonia. Her appetite continued to decline, and she was estimated to have lost about $2.67 \mathrm{~kg}$ since the onset of her symptoms (weight on presentation $21 \mathrm{~kg}$ ). With no response to this second course of antibiotics after a week and the development of mild dyspnea at rest, she was admitted to hospital and seen by the local pediatrician.

A detailed history at this time revealed that the mother, who worked in a pet store, had brought home a pigeon five years before. For the past two years, the pigeon had been brought indoors to protect it from outside predators and had been living in a cage in the kitchen on the same floor as the patient's bedroom. The patient's previous medical and respiratory history were unremarkable. Her nine-year-old sister and two parents were also healthy, but there was a history of asthma in a maternal aunt and paternal grandfather, who incidentally raised pigeons as a hobby.
Physical examination was normal, including temperature and respiratory rate, apart from bilateral basilar fine inspiratory crackles on auscultation and a dry nonproductive cough. Chest $\mathrm{X}$-ray showed a widespread, finely nodular interstitial pattern (Figure 1). Because of the suspicion that she may have had interstitial lung disease from avian antigen, the patient was referred for further evaluation to the Respiratory Division of the Izaak Walton Killam Hospital for Children, Halifax, Nova Scotia.

By this time, she had been out of the home for one-and-ahalf weeks, and her parents described a general improvement in her appearance. Her dyspnea and cough had declined, and her energy and appetite were improving. Physical examination was completely normal, with resolution of the crackles on auscultation and hemoglobin saturation of $98 \%$ on room air. Chest x-ray showed almost complete resolution of the interstitial nodular pattern. Complete blood count was normal. Immunoglobulins (Igs) were essentially normal, and IgE was less than $25 \mathrm{U} / \mathrm{mL}$ (normal 0 to $360 \mathrm{U} / \mathrm{mL}$ ). Erythrocyte sedimentation rate was $10 \mathrm{~mm} / \mathrm{h}$. Because of her age, only spirometry could be performed, which demonstrated a moderately restrictive pattern (Table 1) with no significant response to a bronchodilator. Serum precipitins against pigeon antigen were positive (2).

Because her clinical symptoms had improved simply from being away from the house, no therapy was given and more intensive investigation was not indicated. Before her return home, her parents disposed of the pigeon and cleaned the kitchen. Follow-up one month later confirmed that she had progressed well and returned to her previous state of health. Repeat pulmonary function testing was not available.

\section{DISCUSSION}

The diagnosis of pigeon breeder's disease in this case was made through the recognition of a constellation of clinical features. This diagnosis was supported by a positive assay for serum precipitins against pigeon antigen, and clinical improvement resulted when our patient was removed from contact with the suspected causative agent.

Interstitial lung disease in children more commonly occurs as a result of infectious agents causing interstitial pneumonias. Other causes of pediatric interstitial lung disease include chemical pneumonitides, drugs, radiation, malignancy, collagen vascular disorders, sarcoidosis and idiopathic pulmonary fibrosis (3).

TABLE 1

Spirometry results of a seven-year-old female presenting with a two-month history of gradual onset dyspnea

\begin{tabular}{lccc}
\hline & $\begin{array}{c}\text { Corrected value } \\
\text { prebronchodilator }\end{array}$ & $\begin{array}{c}\text { \% Predicted } \\
\text { prebronchodilator }\end{array}$ & $\begin{array}{c}\% \text { Predicted } \\
\text { postbronchodilator }\end{array}$ \\
\hline Vital capacity (L) & 0.99 & $59 \%$ & $57 \%$ \\
Forced expiratory volume in 1 s (L) & 0.96 & $67 \%$ & $62 \%$ \\
Forced expiratory flow (L/s) & 1.90 & $98 \%$ & $93 \%$ \\
\hline
\end{tabular}


Hypersensitivity pneumonitis is a rare cause of interstitial lung disease in children. The term 'hypersensitivity pneumonitis' was introduced by Fink et al (4) in 1968 and describes a group of diseases resulting from the inhalation of organic dust particles usually between 3 and $5 \mu \mathrm{m}$ in diameter. The term 'extrinsic allergic alveolitis' has also been used to describe the same group of diseases. In children, the majority of cases of hypersensitivity pneumonitis have occurred as a result of exposure to avian proteins (5). In contrast, cases in adults have been attributed to a number of organic antigens, particularly from occupational exposure.

In the acute form of the disease, symptoms usually develop 4 to $6 \mathrm{~h}$ after a relatively brief exposure to high levels of offending antigen. The symptoms include cough, dyspnea, fever, chills, malaise, myalgia, and clinical signs of fever, tachypnea and basilar crackles. Therefore, the acute form may be misdiagnosed as acute bronchitis or pneumonia, especially when accompanied by leukocytosis and pulmonary infiltrates. Children, on the other hand, are more likely to present with chronic symptom onset resulting from prolonged exposure to lower amounts of antigen with the insidious development of progressive dyspnea, anorexia, weight loss and fatigue, such as that seen in our patient, accompanied by the paucity of physical findings and the radiographical findings of diffuse interstitial nodular disease.

Diagnosis of hypersensitivity pneumonitis is dependent on a high index of suspicion and a thorough history including details about the home environment, hobbies and work. Initial investigation should include white blood cell count, chest $\mathrm{x}$-ray and serum precipitin testing. Serum precipitins are indicative of exposure and can be seen in asymptomatic individuals $(6,7)$, but are useful when patients present with the appropriate constellation of clinical findings. Pulmonary function testing reveals a restrictive pattern as seen in our patient. Other investigative procedures might include skin testing, which can be useful with pigeon-derived antigens and some other avian antigens, and inhalation challenges, which can provoke severe reactions.

When the diagnosis remains unclear, lung biopsy and high resolution computed tomography may be helpful. With acute disease, lung pathology may demonstrate an acute granulomatous interstitial pneumonitis, while in the chronic disease, destruction of lung parenchyma and fibrosis are more predominant. Pathological findings, however, are not specific for either the acute or chronic form (8), and do not provide antigen identification, which is paramount to treatment of this condition.

Pigeon breeder's disease is the most common of the pediatric hypersensitivity pneumonitides (8) and was first described by Stiehm et al (1) in 1967. They described a series of five children, all of whom had complete resolution of their symptoms, usually within six months after being removed from contact with pigeons. Only one patient in this series was treated with steroids and returned to normal health one year following. A small number of case reports have followed (9-12) in which patients' symptoms have resolved with either cessation of exposure alone or in conjunction with steroid therapy. In one series described by Keith et al (13) in 1981, four of seven members of a Puerto Rican family were affected, all children from ages 13 to 18 years with a five-year history of exposure. At two-year follow-up, all had resolution of their symptoms after treatment with steroids and relocation to a new home, including a 15 -year-old boy presenting with growth failure, finger clubbing and persistence of restrictive changes on pulmonary function testing.

The mainstay of treatment for hypersensitivity pneumonitis is removal or avoidance of the causative organic agents. In some cases, no further intervention may be required such as for our patient. Re-exposure to the offending agent may result in a recurrence or progression of the disease, with the end result being chronic pulmonary fibrosis. Therapy with corticosteroids may produce a dramatic response in patients with the acute onset form; however, there is controversy regarding its usefulness in the chronic form when lung fibrosis has developed.

\section{CONCLUSIONS}

We are not aware of other pediatric cases of pigeon breeder's disease reported in Nova Scotia, unlike other areas of the world where raising pigeons as a hobby is much more prevalent. However unusual, it remains important to diagnose this disease early because complications can include irreversible pulmonary fibrosis. A thorough history remains the key to diagnosis together with the constellation of other objective findings. Removal of the child from the offending agent may be the only treatment required. We suggest that a complete environmental history be included in the assessment of any child presenting with interstitial lung disease.

ACKNOWLEDGEMENTS: We would like to thank Dr Spencer Lee, Immunology Laboratory, Victoria General Hospital, Halifax, Nova Scotia, and Mike Merriman, Audiovisual Department, Izaak Walton Killam-Grace Health Centre, Halifax, Nova Scotia, for their assistance with this report.

\section{REFERENCES}

1. Stiehm ER, Reed CE, Tooley WH. Pigeon breeder's lung in children. Pediatrics 1967;39:904-15.

2. Elwing H, Nilsson LA, Ouchterlony O. A precipitate adsorption on surface technique: a combination of immunodiffusion and thinlayer immunoassay. Int Arch Allergy Appl Immunol 1977;55:82-5.

3. Laraya-Cuasay LR. Clinical aspects of interstitial lung disease in children. Part I: The history. In: Laraya-Cuasay LR, Hughes WT, eds. Interstitial Lung Diseases in Children, vol 1. Boca Raton: CRC Press Inc, 1988:1-15.

4. Fink JN, Sosman AJ, Barboriak JJ, Schlueter DP, Holmes RA. Pigeon breeders' disease. A clinical study of a hypersensitivity pneumonitis. Ann Intern Med 1968;68:1205-19.

5. Hilman BC. Hypersensitivity pneumonitis. In: Laraya-Cuasay LR, Hughes WT, eds. Interstitial Lung Diseases in Children, vol 3. Boca Raton: CRC Press Inc, 1988:63-70.

6. Cormier Y, Belanger J, Durand P. Factors influencing the development of serum precipitins to farmer's lung antigen in Quebec dairy farmers. Thorax 1985;40:138-42.

7. Cormier Y, Belanger J. The fluctuant nature of precipitating antibodies in dairy farmers. Thorax 1989;44:469-73.

8. Bierman CW, Pierson WE, Massie FS. Non-asthmatic allergic pulmonary disease. In: Chernick V, Kendig EL Jr, eds. Kendig's Disorders of the Respiratory Tract in Children, 5th edn. Montreal: WB Saunders Company, 1990:601-14. 
9. Shannon DC, Andrews JL, Recavarren S, Kazemi H. Pigeon breeder's lung disease and interstitial pulmonary fibrosis. Am J Dis Child 1969;117:504-10.

10. Reiss JS, Weiss NS, Payette KM, Strimas J. Childhood pigeon breeder's disease. Ann Allergy 1974;32:208-12.

11. Chandra S, Jones HE. Pigeon fancier's lung in children. Arch Dis Child
1972;47:716-8.

12. Yee WFH, Castile RG, Cooper A, Roberts M, Patterson R. Diagnosing bird fancier's disease in children. Pediatrics 1990;85:848-52.

13. Keith HH, Holsclaw DS Jr, Dunsky EH. Pigeon breeder's disease in children: A family study. Chest 1981;79:107-10. 


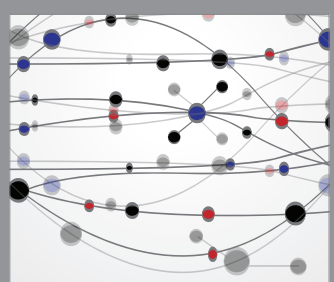

The Scientific World Journal
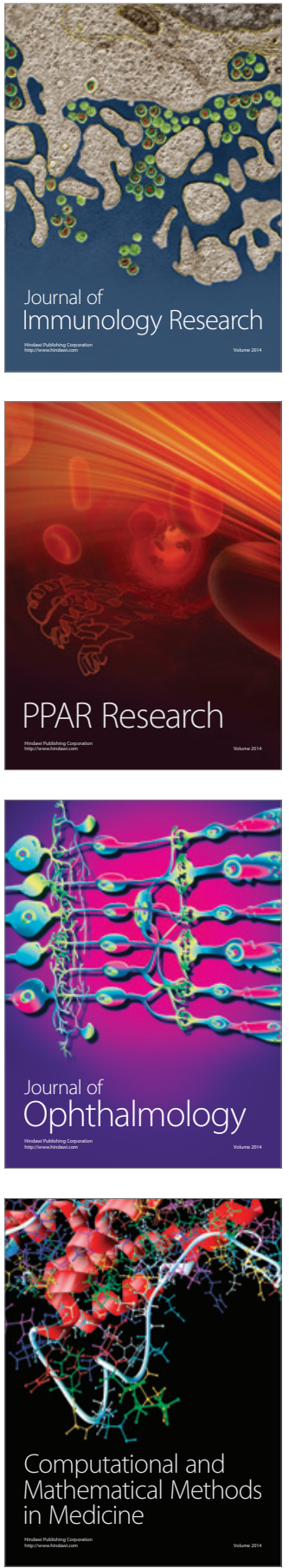

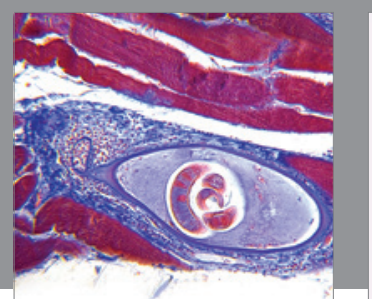

Gastroenterology Research and Practice

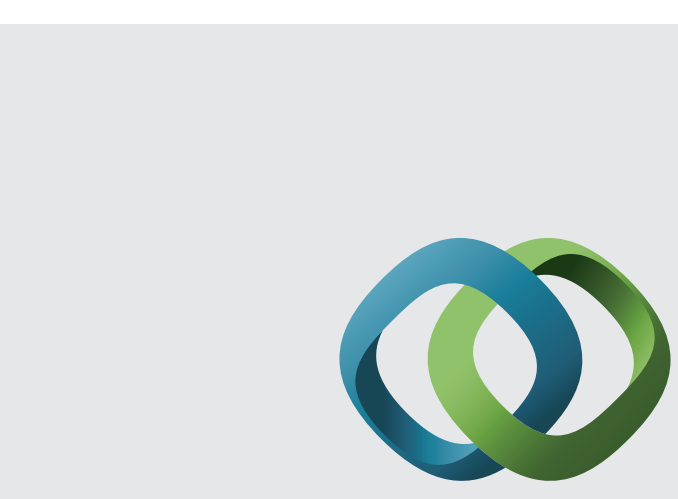

\section{Hindawi}

Submit your manuscripts at

http://www.hindawi.com
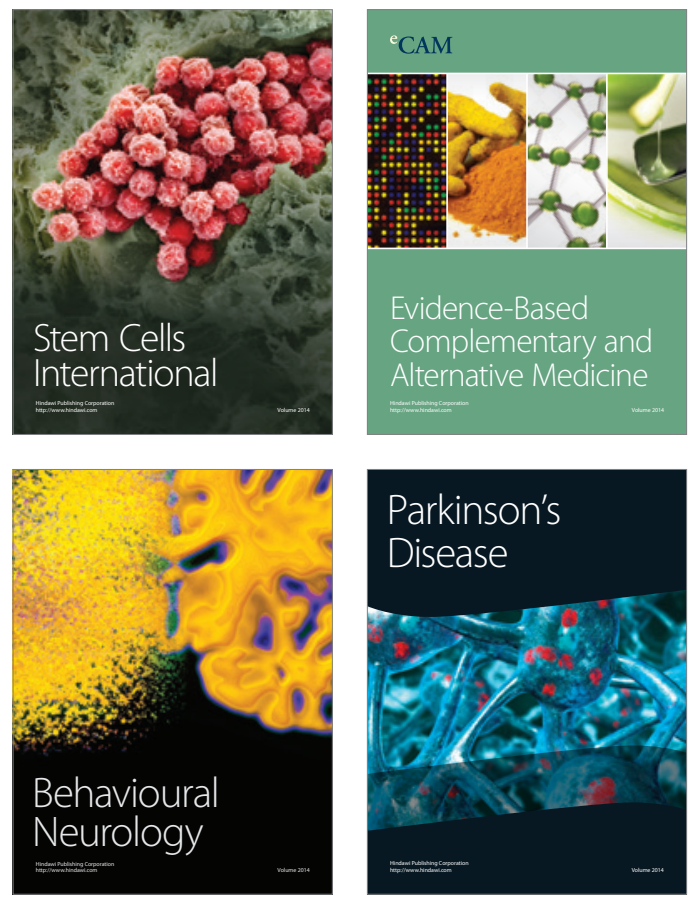
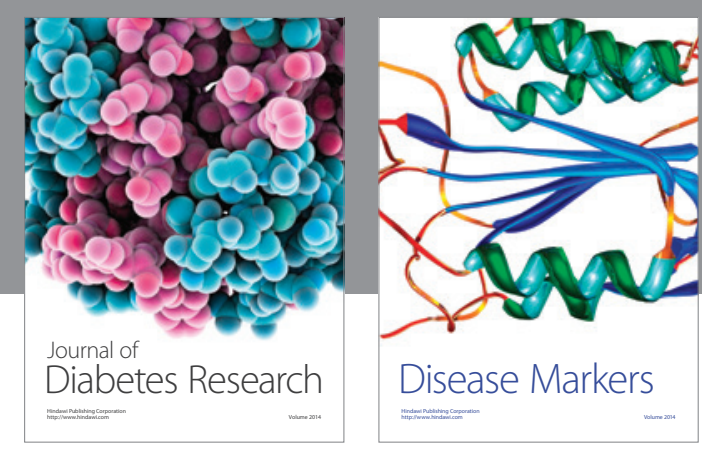

Disease Markers
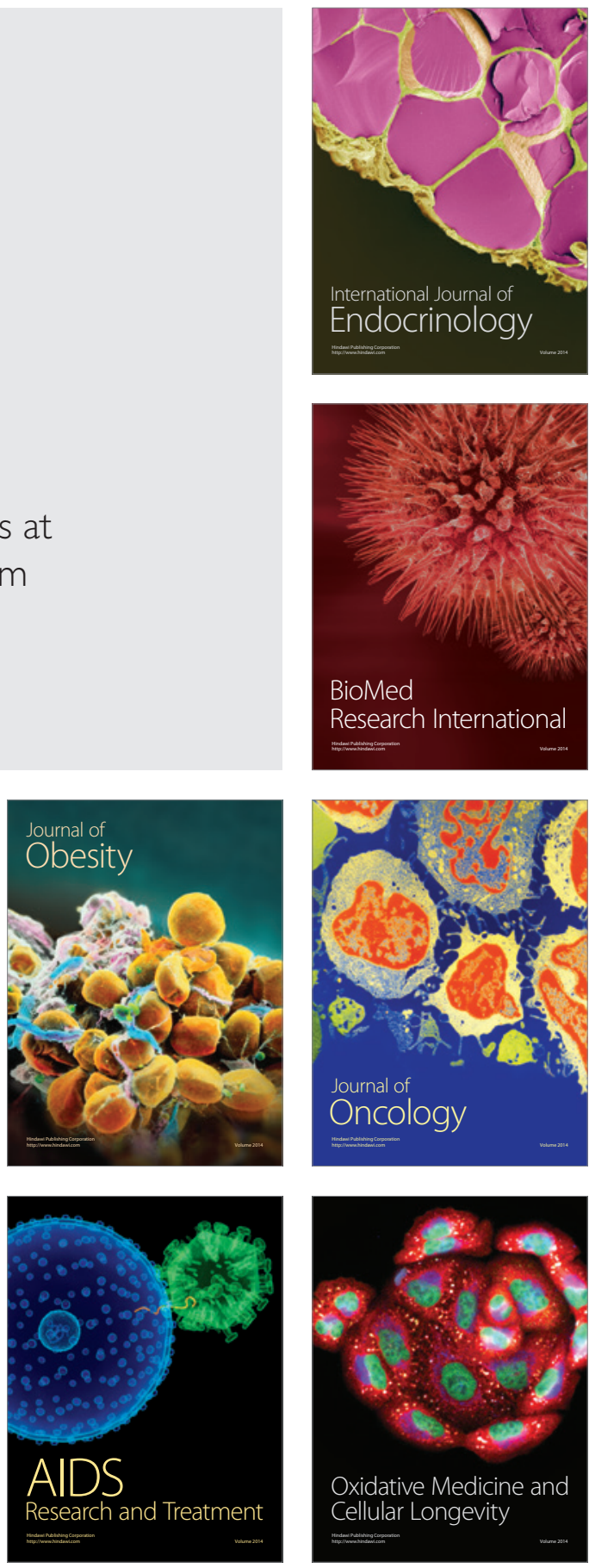